\title{
Omitting surgery in esophageal cancer patients with complete response after neoadjuvant chemoradiotherapy: a systematic review and meta-analysis
}

\author{
Jaehyeon Park®i, Ji Woon Yea, Se An Oh and Jae Won Park
}

\begin{abstract}
Background: Neoadjuvant chemoradiotherapy (nCRT) followed by surgery is a standard treatment modality for locally-advanced esophageal cancer. However, patients who achieve clinical complete response (CCR) after nCRT have been reported to have better prognosis. Further, the role of surgery in these patients is controversial. Thus, this metaanalysis aimed to evaluate whether surgery is still useful in patients with cCR after nCRT.

Methods: We systematically reviewed the MEDLINE, PubMed, Embase, Cochrane library, and Scopus databases for studies on surgical efficacy in complete responders after concurrent chemoradiotherapy for esophageal cancer. The publication date was set to January 1, 2010-January 31, 2020. The hazard ratio (HR) and risk ratio were used to compare the 2-year overall survival (OS), disease-free survival (DFS), incidence of locoregional failure, distant metastasis, and treatment mortality between the nCRT and nCRT plus surgery groups.

Results: Six articles involving 609 patients were included. There was a significant benefit of nCRT for OS (HR $=0.80$, 95\% confidence interval [Cl] 0.64-0.99, $p=0.04$ ), but not for DFS ( $\mathrm{HR}=1.55,95 \% \mathrm{Cl} 0.35-6.86, p=0.56)$. The $\mathrm{nCRT}$ group tended to have lower mortality than the $\mathrm{nCRT}$ plus surgery group (risk ratio $=0.15,95 \% \mathrm{Cl} 0.02-1.18, p=0.07$ ).

Conclusion: Omitting surgery provides better OS in complete responders after nCRT. Adding surgery could increase the morbidity and mortality and decrease the quality of life. Thus, nCRT alone could be a feasible approach for patients with cCR.
\end{abstract}

Keywords: Esophageal cancer, Meta-analysis, Complete response, Neoadjuvant chemoradiotherapy

\section{Background}

The International Agency for Research on Cancer estimates that 450,000 cases of esophageal cancer occurred in 2012 [1]. Esophageal cancer is the sixth leading cause of cancer-related mortality worldwide, and the 5-year survival rate is only approximately $20 \%[2,3]$. Regional differences in incidence and mortality are remarkable,

*Correspondence: kapicap@naver.com

Department of Radiation Oncology, Yeungnam University College

of Medicine, 170, Hyeonchung-ro, Nam-gu, Daegu 705-717, South Korea with high incidence and mortality in Eastern Asia [2]. Surgery is the main curative modality for early stage esophageal cancer. However, most patients are diagnosed at the advanced stage [3]. For locally advanced operable disease, neoadjuvant chemoradiotherapy (nCRT) followed by surgery is recommended as a standard treatment based on the CROSS trial, which showed that nCRT followed by surgery significantly prolonged survival compared to surgery alone [4]. Chemoradiotherapy (CRT) alone is also considered a reasonable option for inoperable patients or those who refuse surgery. Some original author(s) and the source, provide a link to the Creative Commons licence, and indicate if changes were made. The images or other third party material in this article are included in the article's Creative Commons licence, unless indicated otherwise in a credit line to the material. If material is not included in the article's Creative Commons licence and your intended use is not permitted by statutory regulation or exceeds the permitted use, you will need to obtain permission directly from the copyright holder. To view a copy of this licence, visit http://creativecommons.org/licenses/by/4.0/. The Creative Commons Public Domain Dedication waiver (http://creativecommons.org/publicdomain/zero/1.0/) applies to the data made available in this article, unless otherwise stated in a credit line to the data. 
studies have shown no significant difference in survival between nCRT followed by surgery and CRT in locally advanced disease [5-7]. However, nCRT followed by surgery remains the preferred treatment for locally advanced operable disease due to better local control.

Several studies have argued that the wait-and-see approach is also feasible if there is complete remission after nCRT in locally advanced rectal cancer, which had a similar treatment approach with esophageal cancer $[8,9]$. In esophageal cancer, complete remission after nCRT is also known to be a good prognostic factor, with patients in complete remission reported to have lower local recurrence and better survival than those with partial response and non-response $[10,11]$. In the CROSS trial, the rate of pathological complete remission was $29 \%$ [49\% for squamous cell carcinoma (SCC) and $23 \%$ for adenocarcinoma (ACC)] [4]. Therefore, considering the morbidity and mortality, the value of surgery in patients who have shown complete remission after $\mathrm{nCRT}$ is debatable.

A recent prospective study on the role of surgery in patients with complete remission after nCRT [12] has shown no significant difference in survival and locoregional failure (LF) rates between the surgery and nonsurgery groups. The authors concluded that close observation with salvage surgery could be a reasonable choice in patients who achieved complete remission after nCRT. However, the number of enrolled patients was very small, and the conclusions about the role of surgery are still unclear. Thus, this systematic review and metaanalysis aimed to evaluate the usefulness of surgery in patients with complete remission after nCRT.

\section{Methods}

\section{Search strategy and study selection}

A systematic literature search was performed using the MEDLINE, PubMed, Embase, Cochrane library, and Scopus databases. We considered all studies on the therapeutic value of surgery in complete responders after concurrent CRT for esophageal cancer. The publishing date was set to between January 1, 2010 and January 31,2020 . The following terms were used for search: (esophageal OR esophagus OR oesophageal) AND (carcinoma OR neoplasm OR tumor) AND (chemoradiation OR chemoradiotherapy OR radiochemotherapy OR chemo-irradiation OR chemo-radiotherapy) AND (complete OR response OR responder OR complete response OR complete responder). The inclusion criteria were as follows: (1) studies on patients with esophageal cancer treated with concurrent CRT; (2) studies on patients who achieved clinical complete remission after concurrent CRT; and (3) studies comparing treatment outcomes between patients with esophageal cancer treated with and without surgery. The exclusion criteria were: (1) comparing radiotherapy or CRT with surgery alone; (2) reviews or case reports, with other sites of cancers, and meta-analysis; (3) unclear results; and (4) studies in written in language other than English.

\section{Quality assessment}

The quality of the included studies was independently assessed by two investigators according to the type of the study. The Cochrane Collaboration's tool was adopted for assessment of the randomized controlled trial. The quality evaluation included: method of randomization, allocation concealment, blinding, integrity of result data, results of selective reporting, and other sources of bias. Each element was qualified as high, low, or unclear risk of bias. The Newcastle-Ottawa Quality Assessment Scale for case-control studies was used to assess non-randomized studies. High quality was defined as $6-7$ low risk of bias and score 7-10; moderate quality, 3-5 low risk of bias and score 4-6; and low quality, less than 3 risk of bias and score less than 4 (Additional file 3: Fig. S1; Additional file 1: Table S1). Disagreements were resolved by consensus between two authors.

\section{Data extraction and synthesis}

After duplicate publications were deleted, two authors (J.P and J.W.P) independently evaluated potentially eligible studies that were identified by our search. Articles were screened for eligibility based on a review of the title and abstract. Then, the full text of eligible articles was accessed and read independently by two authors (J.P and J.W.P). Next, relevant data were extracted from the eligible studies. These included the first author, country, year of publication, study period, type of study, sample size, age, chemotherapy regimens, and radiation dose. Treatment outcome data included the 2-year overall survival (OS), disease-free survival (DFS), incidence of LF, distant metastasis (DM), and mortality. Patients who showed both LF and DM were classified in the DM group. If the hazard ratio (HR) and 95\% confidence interval (CI) were not available, an estimate value was calculated by using the methods described by Tierney et al. [13]. Survival rates from Kaplan-Meier curves were read using Graph Grabber version 2.0.2 (Quintessa Ltd, England), and the resulting data were then entered in the calculation spreadsheet appended to Tierney's paper.

\section{Statistical analyses}

All analyses were performed using Review Manager Version 5.3. All statistical tests were two-sided. The relative risk (RR) or HR and its $95 \% \mathrm{CI}$ was used to quantify the incidence of LF, DM, and treatment mortality, as well as the 2-year OS and DFS. When using the RR for evaluation, the significance was assessed using the 
Mantel-Haenszel test. In addition, inverse variance test was adopted when the HR was estimated. Q tests and $\mathrm{I}^{2}$ tests were adopted to estimate heterogeneity. Publication bias was evaluated using a funnel plot.

\section{Results}

\section{Study characteristics}

Of the 5777 articles identified, 1256 duplicates were removed. After title and abstract screening, 13 articles were evaluated for their full text. Finally, six articles were included in the analyses (Fig. 1). The detailed characteristics of these included studies are summarized in Table 1 . Only one study was a randomized prospective study, and the rest were retrospective studies. The studies were published in 2013-2019 and included a total of 609 patients who had clinical complete response (cCR) after nCRT. Of them, 353 and 256 patients were categorized to the nCRT plus surgery and nCRT groups, respectively. By histology, 509, 99, and one patient(s) had SCC, ACC, and adenosquamous carcinoma, respectively.

Three studies were from Asia (two from South Korea and one from Taiwan), and the other three were from Western countries (one each from France, Italy, and the Netherlands). Induction chemotherapy followed by nCRT was performed in three studies, while nCRT was administered before surgery in the other three studies. The total delivered radiation dose ranged from $30 \mathrm{~Gy}$ from $60 \mathrm{~Gy}$. Two studies $[12,14]$ reported the HR and $95 \%$ CI of OS and DFS. Those of the remaining four studies [15-18] were estimated based on the KaplanMeier curves using the method mentioned above.
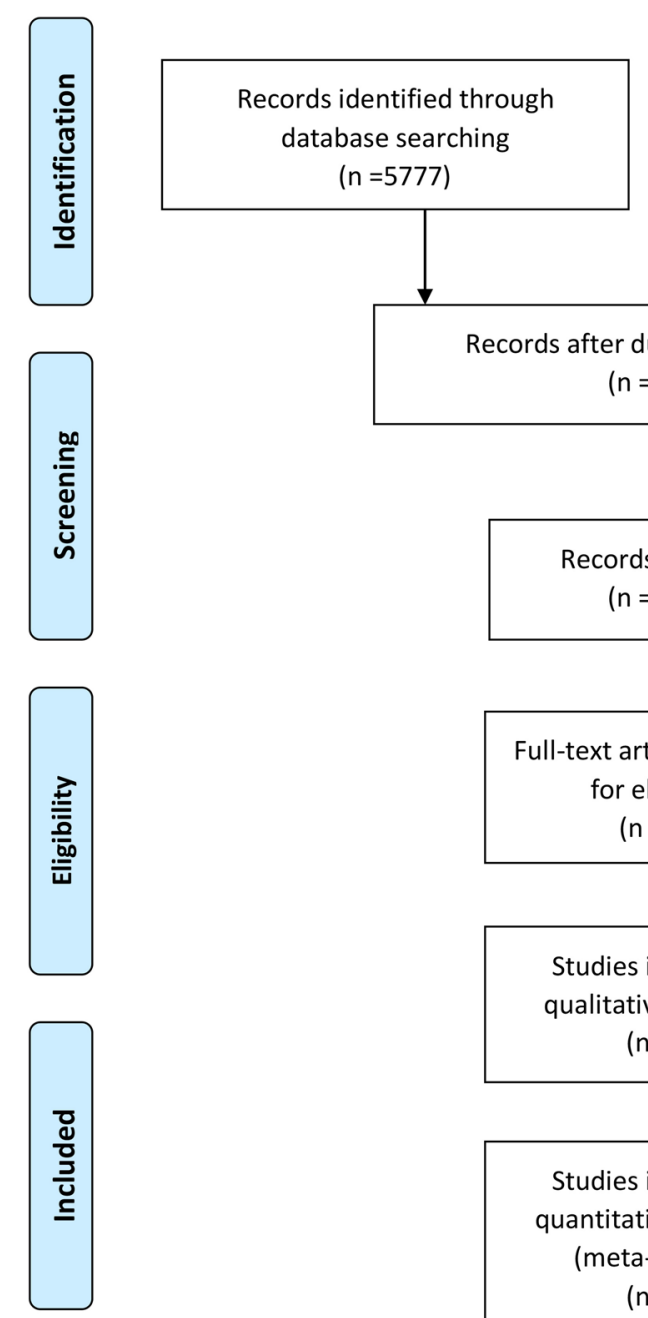

Records after duplicates removed

( $n=4521$ )

Additional records identified through other sources $(n=0)$
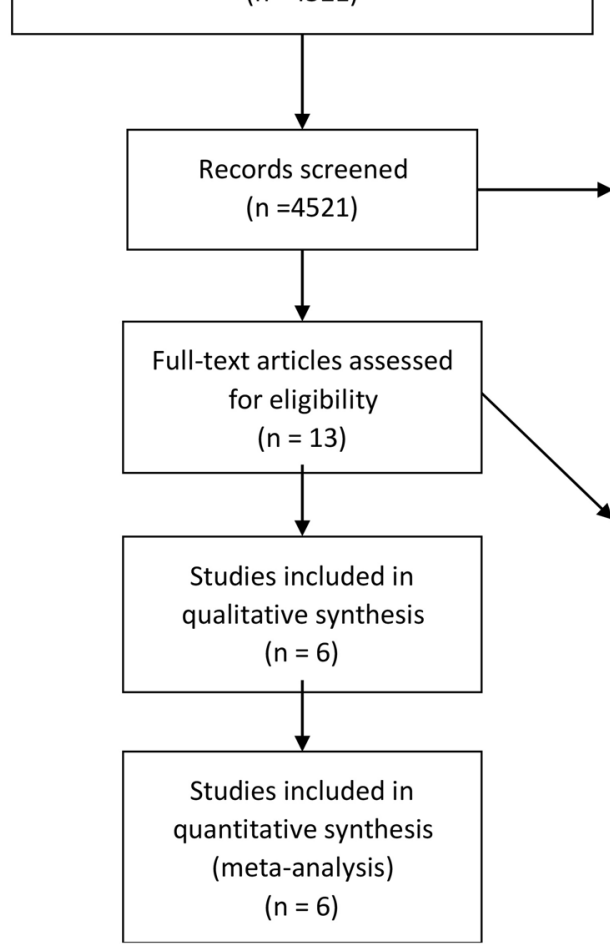

Records excluded $(n=4458)$

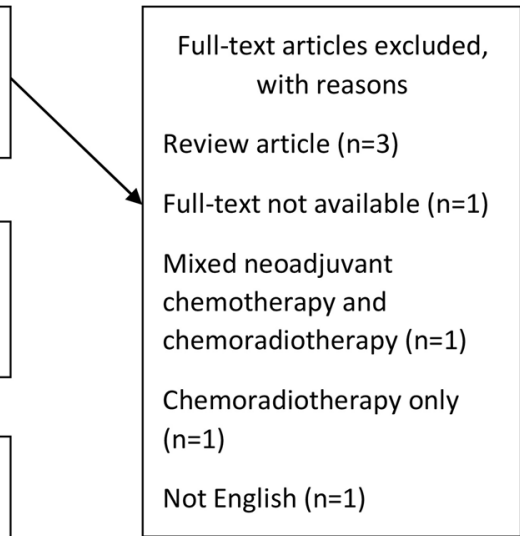

Fig. 1 PRISMA flow diagram 
Table 1 Characteristics of the included studies

\begin{tabular}{|c|c|c|c|c|c|c|c|c|}
\hline $\begin{array}{l}\text { Author } \\
\text { (study } \\
\text { period) }\end{array}$ & Nation & $\begin{array}{l}\text { Study } \\
\text { design }\end{array}$ & $\begin{array}{l}\text { No. of } \\
\text { patients }\end{array}$ & $\begin{array}{l}\text { Clinical } \\
\text { stage }\end{array}$ & $\begin{array}{l}\text { Neoadjuvant } \\
\text { chemoradiotherapy } \\
\text { (nCRT) }\end{array}$ & $\begin{array}{l}\text { Work-up } \\
\text { after nCRT }\end{array}$ & $\begin{array}{l}\text { Outcome } \\
(2 \mathrm{yr}-\mathrm{OS} \\
(\%) / 2 \mathrm{yr}-\mathrm{DFS} \\
(\%))\end{array}$ & $\begin{array}{l}\text { Quality } \\
\text { assessment }^{\text {b }}\end{array}$ \\
\hline $\begin{array}{l}\text { Castro [15] } \\
(1992- \\
2007)\end{array}$ & Italy & $\begin{array}{l}\text { Retrospec- } \\
\text { tive }\end{array}$ & $\begin{array}{l}\text { nCRT }(n=38) \text { SCC only } \\
n C R T+S \\
(n=39)\end{array}$ & II-IV & $\begin{array}{l}\text { nCRT } 45-50 \text { Gy in } \\
1.8 \text { Gy daily fraction } \\
\text { with FP }\end{array}$ & $\begin{array}{l}\text { Endoscopy } \\
\text { with biop- } \\
\text { sies, CT }\end{array}$ & $\begin{array}{l}72.2 / 39.8 \\
72.2 / 64.8\end{array}$ & Moderate \\
\hline $\begin{array}{l}\text { Chao }[16] \\
(1996- \\
2006)\end{array}$ & Taiwan & $\begin{array}{l}\text { Retrospec- } \\
\text { tive }\end{array}$ & $\begin{array}{l}\text { nCRT }(\mathrm{n}=79) \text { SCC only } \\
\quad \mathrm{nCRT}+\mathrm{S} \\
(\mathrm{n}=71)\end{array}$ & $\|-I V^{a}$ & $\begin{array}{l}\text { Induction } \\
\text { FP\# } 1+\text { nCRT } 30 \text { Gy/15 } \\
\text { fx with FP boost } \\
30 \text { Gy/15fx (pT3 or } \\
\text { pN + in in surgery or } \\
\text { in without surgery) }\end{array}$ & $\begin{array}{l}\text { Endoscopy } \\
\text { with biop- } \\
\text { sies, CT }\end{array}$ & $\begin{array}{l}62.8 \\
56.1\end{array}$ & Moderate \\
\hline $\begin{array}{l}\text { Piessen [17] } \\
(1995- \\
2012)\end{array}$ & France & $\begin{array}{l}\text { Retrospec- } \\
\text { tive }\end{array}$ & $\begin{array}{l}\text { nCRT }(n=59) \text { SCC } \\
(n=149) \\
n C R T+S \text { ADC } \\
(n=118) \quad(n=28)\end{array}$ & $\|-\| \|$ & $\begin{array}{l}\text { nCRT } 45 \text { Gy/25 fx } \\
\text { with FP }\end{array}$ & $\begin{array}{l}\text { Endoscopy } \\
\text { with biop- } \\
\text { sies, barium } \\
\text { swallow, CT } \\
\text { (PET was } \\
\text { used selec- } \\
\text { tively.) }\end{array}$ & $\begin{array}{l}58.0 / 58.2 \\
81.0^{*} / 80.4^{*}\end{array}$ & High \\
\hline $\begin{array}{l}\text { Jeong }[14] \\
(2005- \\
2008)\end{array}$ & Korea & $\begin{array}{l}\text { Retrospec- } \\
\text { tive }\end{array}$ & $\begin{array}{l}\text { nCRT }(n=31) \text { SCC only } \\
n C R T+S \\
(n=39)\end{array}$ & $\|-I V^{a}$ & $\begin{array}{l}\text { Induction } \\
\text { XP\#2 + nCRT with XP } \\
\text { nCRT + S: } 46 \text { Gy/23 fx } \\
\text { nCRT: } 54 \text { Gy/27 fx }\end{array}$ & $\begin{array}{l}\text { Endoscopy } \\
\text { with or } \\
\text { without } \\
\text { biopsy, EUS, } \\
\text { CT, PET }\end{array}$ & $\begin{array}{l}61.3 / 47.3 \\
71.8 / 83.0^{*}\end{array}$ & Moderate \\
\hline $\begin{array}{l}\text { Wilk [18] } \\
(2013- \\
2016)\end{array}$ & Netherland & $\begin{array}{l}\text { Retrospec- } \\
\text { tive }\end{array}$ & $\begin{aligned} & \text { nCRT }(n=29) \text { SCC } \\
&(n=26) \\
& \text { ADC } \\
&(n=71) \\
& n C R T+S \text { ADSC } \\
&(n=29) \quad(n=1)\end{aligned}$ & $\|-\mid\|$ & $\begin{array}{l}\text { nCRT } 41.4 \mathrm{~Gy} / 23 \mathrm{fx} \\
\text { with PC }\end{array}$ & $\begin{array}{l}\text { Endos- } \\
\text { copy with } \\
\text { biopsies } \\
\text { (bite-on- } \\
\text { bite), EUS, } \\
\text { PET }\end{array}$ & $89.7 / 73.5$ & High \\
\hline $\begin{array}{l}\text { Park [12] } \\
(2012- \\
2016)\end{array}$ & Korea & Prospective & $\begin{array}{l}\text { nCRT }(n=18) \text { SCC only } \\
\text { nCRT }+S \\
(n=19)\end{array}$ & $\|-\mid\|$ & $\begin{array}{l}\text { Induction } \\
\text { XP\#2 + nCRT with XP } \\
50.4 \text { Gy/28 fx with XP }\end{array}$ & $\begin{array}{l}\text { Endoscopy } \\
\text { with or } \\
\text { without } \\
\text { biopsy, EUS, } \\
\text { CT, PET }\end{array}$ & $\begin{array}{l}72.8 / 42.7 \\
74.4 / 66.7\end{array}$ & Moderate \\
\hline
\end{tabular}

$n C R T$ neoadjuvant chemoradiotherapy, $n C R T+$ surgery neoadjuvant chemoradiotherapy followed by surgery, SCC squamous cell carcinoma, $A D C$ adenocarcinoma, $A D S C$ adenosquamous cell carcinoma, CT computed tomography, PET positron emission tomography, EUS endoscopic ultrasonography, FP 5-fluorouracil/cisplatin, XP cisplatin/capecitabine, $P C$ carboplatin/paclitaxel, OS overall survival, DFS disease-free survival

${ }^{\text {a }}$ Distant metastasis, lymph node metastasis other than regional LN

${ }^{\mathrm{b}}$ Assessed using the Newcastle-Ottawa Quality Assessment Scale for retrospective studies and The Cochrane Collaboration's tool for prospective studies

*Statistically significant

\section{Overall survival and disease-free survival}

For OS assessment, there was no significant heterogeneity for the results among the studies $(p=0.95$, $\left.\mathrm{I}^{2}=0 \%\right)$; thus, a fixed-effects model was used for further analysis. As shown in Fig. 2a, patients in the nCRT group had significantly better OS than those in the nCRT plus surgery group ( $\mathrm{HR}=0.80,95 \% \mathrm{CI} 0.64-$ $0.99, p=0.04)$.

For DFS assessment, there was also no significant heterogeneity for the results among the studies $(p=0.99$, $\mathrm{I}^{2}=0 \%$ ); thus a fixed-effects model was used for further analysis. In contrast to OS, we found no significant difference in DFS between the nCRT and nCRT plus surgery groups $(\mathrm{HR}=1.55,95 \% \mathrm{CI} 0.35-6.86, p=0.56$; Fig. $2 \mathrm{~b})$.

\section{Patterns of failure and treatment mortality}

Data on failure rate according to recurrence type were available in four studies. The incidence rate of locoregional recurrence (LR) was significantly lower in the nCRT plus surgery group than in the nCRT group $(\mathrm{RR}=3.61,95 \% \mathrm{CI} 2.30-5.67, p<0.001)$. Meanwhile, the nCRT group had a significantly lower DM rate than the nCRT plus surgery group $(\mathrm{RR}=0.60,95 \%$ CI $0.43-0.85$, $p=0.004$; Fig. 3).

Only three studies reported on treatment mortality (Fig. 4). The nCRT group tended to have lower mortality than the nCRT plus surgery group, although the difference was not statistically significant $(R R=0.15,95 \%$ CI $0.02-1.18, p=0.07)$. 


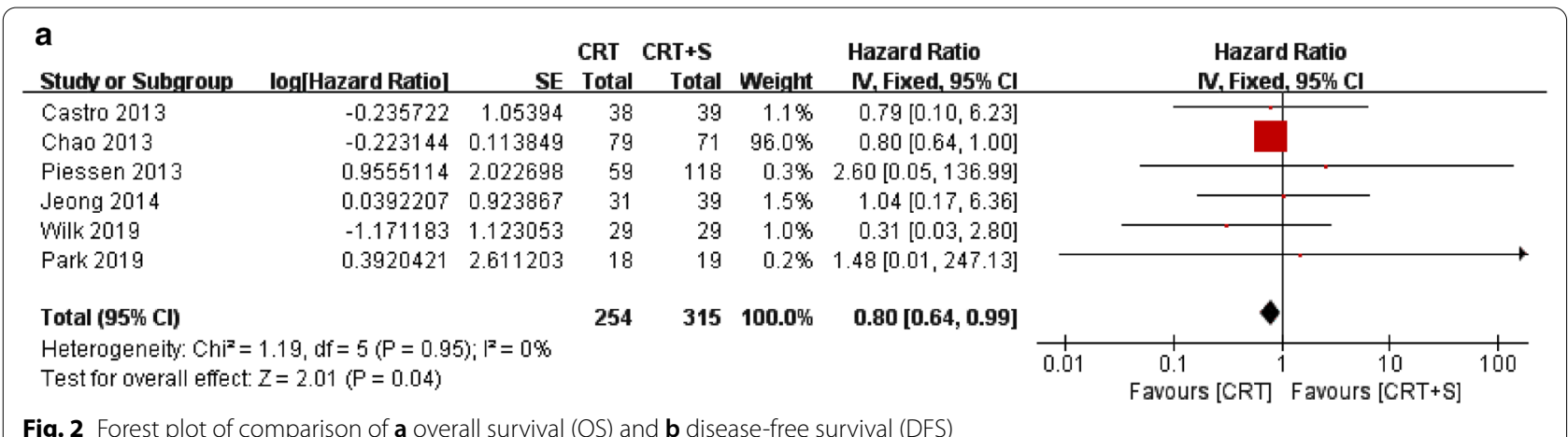

\begin{tabular}{|c|c|c|c|c|c|c|c|c|c|c|}
\hline $\begin{array}{l}\text { b } \\
\text { Studv or Subgroup }\end{array}$ & log[Hazard Ratiol & SE & $\begin{array}{l}\text { CRT } \\
\text { Total }\end{array}$ & $\begin{array}{c}\text { CRT+S } \\
\text { Total } \\
\end{array}$ & Weight & $\begin{array}{l}\text { Hazard Ratio } \\
\text { N, Fixed, 95\% Cl }\end{array}$ & & $\begin{array}{r}\text { Hazard } \\
\text { N, Fixed, }\end{array}$ & $\begin{array}{l}\text { d Ratio } \\
\text { d, 95\% Cl }\end{array}$ & \\
\hline Castro 2013 & 0.4187103 & 1.3526988 & 38 & 39 & $31.5 \%$ & $1.52[0.11,21.54]$ & & & $=$ & \\
\hline Piessen 2013 & 0.8878913 & 1.8990351 & 59 & 118 & $16.0 \%$ & $2.43[0.06,100.48]$ & & & & \\
\hline Jeong 2014 & 1.0228106 & 2.1750966 & 31 & 39 & $12.2 \%$ & $2.78[0.04,197.54]$ & & & & \\
\hline Wilk 2019 & -0.116534 & 1.4472111 & 29 & 29 & $27.5 \%$ & $0.89[0.05,15.18]$ & & & & \\
\hline Park 2019 & 0.5596158 & 2.122645 & 18 & 19 & $12.8 \%$ & $1.75[0.03,112.16]$ & & & & \\
\hline \multirow{2}{*}{\multicolumn{3}{|c|}{$\begin{array}{l}\text { Total }(\mathbf{9 5} \% \mathbf{C l}) \\
\text { Heterogeneity: Chi }=0.28, \mathrm{df}=4(\mathrm{P}=0.99) ; \mathrm{I}^{2}=0 \% \\
\text { Test for overall effect: } \mathrm{Z}=0.58(\mathrm{P}=0.56)\end{array}$}} & 175 & 244 & $100.0 \%$ & $1.55[0.35,6.86]$ & & & & \\
\hline & & & & & & & 0.001 & $\begin{array}{c}0.1 \\
\text { Favours [CRT] }\end{array}$ & Favours [CRT+S] & 1000 \\
\hline
\end{tabular}

\begin{tabular}{|c|c|c|c|c|c|c|c|c|c|c|}
\hline $\begin{array}{l}\text { a } \\
\text { Study or Subgroup }\end{array}$ & $\begin{array}{l}\text { nCRT } \\
\text { Events } \\
\end{array}$ & Total & $\begin{array}{l}\text { nCRT+ } \\
\text { Events }\end{array}$ & $\begin{array}{l}\text { S } \\
\text { Total }\end{array}$ & Weight & $\begin{array}{c}\text { Risk Ratio } \\
\text { M-H. Fixed. } 95 \% \mathrm{Cl}\end{array}$ & & $\begin{array}{r}\text { Risk R } \\
\text { M-H, Fixed }\end{array}$ & $\begin{array}{l}\text { Ratio } \\
\text { d. } 95 \% \mathrm{Cl}\end{array}$ & \\
\hline Castro 2013 & 15 & 35 & 7 & 36 & $35.9 \%$ & $2.20[1.02,4.75]$ & & & $\square$ & \\
\hline Chao 2013 & 29 & 79 & 5 & 71 & $27.4 \%$ & $5.21[2.13,12.74]$ & & & & \\
\hline Piessen 2013 & 14 & 59 & 6 & 113 & $21.4 \%$ & $4.47[1.81,11.03]$ & & & & \\
\hline Park 2019 & 8 & 18 & 3 & 19 & $15.2 \%$ & $2.81[0.88,8.98]$ & & & . & \\
\hline Total $(95 \% \mathrm{Cl})$ & & 191 & & 239 & $100.0 \%$ & $3.61[2.30,5.67]$ & & & & \\
\hline Total events & 66 & & 21 & & & & & & & \\
\hline \multicolumn{5}{|c|}{$\begin{array}{l}\text { Heterogeneity: } \mathrm{Chi}^{2}=2.63, \mathrm{df}=3(P=0.45) ; I^{2}=0 \% \\
\text { Test for overall effect: } Z=5.57(P<0.00001)\end{array}$} & & & 0.01 & $\begin{array}{c}0.1 \\
\text { Favours [nCRT] }\end{array}$ & $\begin{array}{c}10 \\
\text { Favours [nCRT+S] }\end{array}$ & 100 \\
\hline
\end{tabular}

\begin{tabular}{|c|c|c|c|c|c|c|c|c|c|c|}
\hline $\begin{array}{l}\text { b } \\
\text { Study or Subgroup }\end{array}$ & $\begin{array}{l}n C R T \\
\text { Events }\end{array}$ & Total & $\begin{array}{l}\text { nCRT } \\
\text { Events }\end{array}$ & $\begin{array}{l}\text { S } \\
\text { Total }\end{array}$ & Weight & $\begin{array}{c}\text { Risk Ratio } \\
\text { M-H. Fixed. } 95 \% \mathrm{Cl}\end{array}$ & & $\begin{array}{r}\text { Risk F } \\
\text { M-H. Fixe }\end{array}$ & $\begin{array}{l}\text { Ratio } \\
\text { d. } 95 \% \mathrm{Cl}\end{array}$ & \\
\hline Castro 2013 & 4 & 35 & 7 & 36 & $10.7 \%$ & $0.59[0.19,1.83]$ & & & E & \\
\hline Chao 2013 & 14 & 79 & 31 & 71 & $50.8 \%$ & $0.41[0.24,0.70]$ & & & & \\
\hline Piessen 2013 & 16 & 59 & 31 & 113 & $33.1 \%$ & $0.99[0.59,1.65]$ & & & - & \\
\hline Park 2019 & 0 & 18 & 3 & 19 & $5.3 \%$ & $0.15[0.01,2.72]$ & $\longleftarrow$ & & & \\
\hline Total $(95 \% \mathrm{Cl})$ & & 191 & & 239 & $100.0 \%$ & $0.60[0.43,0.85]$ & & & & \\
\hline Total events & 34 & & 32 & & & & & & & \\
\hline \multicolumn{5}{|c|}{$\begin{array}{l}\text { Heterogeneity: } \mathrm{Chi}^{2}=6.46, \mathrm{df}=3(P=0.09) ; I^{2}=54 \% \\
\text { Test for overall effect: } Z=2.86(P=0.004)\end{array}$} & & & 0.01 & $\begin{array}{c}0.1 \\
\text { Favours [nCRT] }\end{array}$ & $\begin{array}{c}10 \\
\text { Favours [nCRT+S] }\end{array}$ & 100 \\
\hline
\end{tabular}




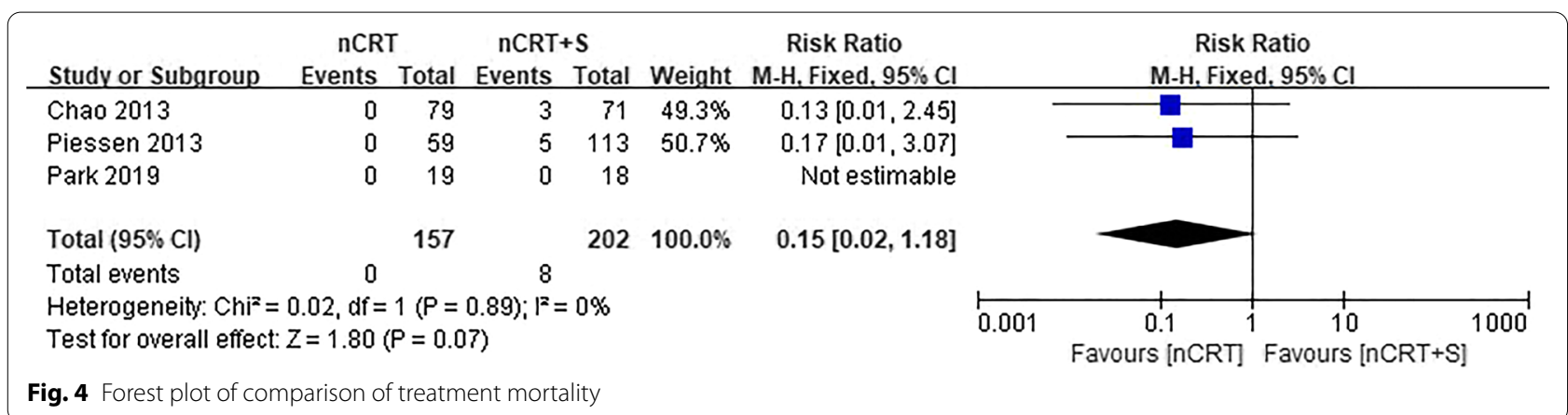

\section{Sensitivity analysis and publication bias}

Sensitivity analysis was applied by sequentially removing each study, and the results were stable (Additional file 2: Table S2). Publication bias statistical analysis performed using the funnel plot also showed that no publication bias exists in the meta-analysis (Additional file 4: Fig. S2).

\section{Discussion}

The role of surgery in patients who achieve $\mathrm{CCR}$ after nCRT is controversial. This systematic review and meta-analysis showed that nCRT alone has better survival benefit than nCRT plus surgery. There was no significant difference in DFS $(\mathrm{HR}=1.55,95 \% \mathrm{CI}$ 0.35-6.86). This survival benefit in nCRT may be attributed to the lower mortality in the nCRT group than in the nCRT plus surgery group and the pattern of failure between nCRT and nCRT plus surgery. Specifically, nCRT plus surgery showed better local control, although it also showed a higher incidence of distant failure than nCRT.

Currently, nCRT plus surgery is the preferred approach for locally advanced operable esophageal cancer. One study showed that salvage esophagectomy provides patients with LR a chance for long-term survival [19]. CRT alone is also a feasible option for these patients, and several studies showed no benefit of the addition of surgery [5-7]. Thus, it raises the question of whether surgery is of benefit in locally advanced operable esophageal cancer. Particularly, in the case of complete responders after nCRT, who are known to have low recurrence rates and high survival rates [20], omitting surgery could be more beneficial because it avoids the morbidity and mortality associated with the addition of surgery. Wilk et al. retrospectively compared the treatment outcomes between active surveillance and immediate surgery in patients with $\mathrm{CCR}$ after nCRT [18] and found that although there was no statistical difference, the survival rates were higher in the active surveillance group (3-year OS $=77 \%$ vs. $55 \%, p=0.10$; 3 -year progression-free survival $[\mathrm{PFS}]=60 \%$ vs. $54 \%$, $p=0.87$ ). Meanwhile, a recent prospective study showed that nCRT is associated with a higher relapse rate and a lower survival rate $(\mathrm{HR}=1.17, p=0.28$ for PFS; $\mathrm{HR}=1.48, p=0.56$ for OS) [12]. The $\mathrm{cCR}$ rate was $47.6 \%$, which is approximately $7 \%$ higher than that reported in Wilk' study. However, the two studies differed in the assessment of $\mathrm{cCR}$, as the former used a bite-on-bite biopsy and the latter a regular biopsy. The recently published preSANO study revealed that compared with regular biopsies, the sensitivity for the detection of residual disease increased substantially from 54 to $74 \%$ with bite-on-bite biopsies [21]. We could presume that inclusion of more patients with false-negative results could cause a detrimental effect on the analysis of treatment outcomes of nCRT.

Thus, the important issue is the accuracy of $\mathrm{cCR}$ for predicting pathologic $\mathrm{CR}(\mathrm{pCR})$ and its reliability as an indicator for omitting surgery in $\mathrm{CCR}$ after nCRT in esophageal cancer. Endoscopy or endoscopic ultrasonography (EUS) with biopsy, computed tomography (CT), and positron emission tomography (PET)-CT are generally used to evaluate treatment response after nCRT. However, no single modality could produce satisfactory results. A meta-analysis on the accuracy of modalities showed pooled sensitivities and specificities of respectively $33 \%$ and $95 \%$ for endoscopic biopsies, $96 \%$ and $8 \%$ for qualitative EUS, $74 \%$ and $52 \%$ for qualitative PET, $69 \%$ and $72 \%$ for PET using the maximum standardized uptake value $\left(\mathrm{SUV}_{\max }\right)$, and $73 \%$ and $63 \%$ for PET using percentage reduction of $S U V_{\max }$ [22]. A systematic study reported that the negative predictive value of negative endoscopy biopsy after CRT was only 47\% [23]. Cheedella et al. reported the result of response evaluation after CRT using endoscopy with biopsy and the $\mathrm{SUV}_{\max }$ of PET-CT [24]. The sensitivity of CCR for pCR was $97.1 \%$, and the specificity was $29.8 \%$. They concluded that cCR is not highly associated with PCR due to the low specificity. However, magnetic resonance imaging (MRI) is emerging 
as a promising method for response evaluation as it was highly predictive of histopathologic response and has the potential benefit of a multiparametric approach using diffusion-weighted and dynamic contrast-enhanced imaging $[25,26]$. A recent prospective study reported that PET and MRI are effective in predicting pathologic response [27]. In addition, this study reported that a combined model of MRI, PET, and histology could improve the predictive rate compared with using each modality alone (c-statistic 0.84 vs. 0.79 ).

There are ongoing efforts to identify factors that can predict the response of esophageal cancer by neoadjuvant treatment. Sherry et al. showed that dynamic timedependent changes in the neutrophil-to-lymphocyte ratio (NLR) during $\mathrm{nCRT}$ predict response and clinical outcomes [28]. Increasing NLR was associated with a reduced probability of $\mathrm{pCR}$ (odds ratio $=0.80, p=0.03$ ), shortened DFS $(\mathrm{HR}=1.02, p<0.01)$, and reduced OS $(\mathrm{HR}=1.02, p<0.01)$. Maher et al. reported that good responders to nCRT can be predicted with low pretreatment complement C3a and C4 [29]. As cancer genetics research progresses, both biochemical and molecular predictive factors have been proposed. P53 (a well-known tumor suppressor gene) and excision-repair cross-contemplating 1 (ERCC1) (an important enzyme in the nucleotide excision repair pathway), are representative. According to a meta-analysis, wild-type p53 had a high pCR rate to $\mathrm{nCRT}$ in $\mathrm{SCC}(\mathrm{RR}=1.13, p=0.04)$ [30]. Also, the low level of ERCC1 mRNA expression is associated with a superior response to platinum-based chemotherapy in SCC [31]. Metager et al. showed that ERCC1 (rs11615) gene polymorphisms are associated with response and survival in patients with ACC who underwent nCRT [32].

Surgery has a major impact on the patient's quality of life (QOL). Boehier et al. investigated long-term QOL and symptom evolution up to 20 years after esophagectomy [33] and found that esophagectomy was associated with decreased QOL and lasting gastrointestinal symptoms up to 20 years after surgery. Meanwhile, CRT negatively affects the QOL during treatment, although it mostly recovered afterwards. Noordman et al. reported that a negative impact of nCRT on QOL was observed only during the last cycle of CRT and up to 2 weeks after CRT [34]. Physical functioning, odynophagia, and sensory symptoms were restored to baseline levels from 1 to 2 months after nCRT. Odynophagia, fatigue, and weight loss improved after nCRT within 4 months.

In this study, the risk of treatment mortality was lower in nCRT than in nCRT plus surgery. However, this does not include mortality after salvage surgery in cases of LR in nCRT. Several previous studies report that patients who receive salvage surgery have high morbidity and mortality, with anastomosis leakage occurring in $21-38 \%$ and the mortality ranging from $4 \%-33 \%$. Meanwhile, survival was similar to that of patients who received planned surgery [35-39]. However, these results should be interpreted with caution due to the inclusion of inoperable patients who received high-dose radiotherapy (>60 Gy). Notably, the morbidity and mortality have greatly reduced in the recent decade, and the differences of those between planned and salvage surgery have also reduced. In the MD Anderson Cancer Center (UICC), comparison between the early (1987-2000) and modern eras (1997-2010) showed that the mortality rate decreased from 6 to $3 \%$ for planned surgery and from 15 to $5 \%$ for salvage surgery [40]. Indeed, better survival in nCRT may reflect advancements in surgical techniques, lower radiotherapy doses, and selection of patient with $\mathrm{CCR}$.

Recently, research on proton beam therapy (PBT), an emerging advanced radiotherapy technology, is being actively conducted for esophageal cancer. The esophagus is anatomically located in the midline and surrounded by critical organs (i.e., the heart and lungs). Featuring the highest dose at the Bragg peak and rapid dose fall off beyond that point [41], PBT can reduce the radiotherapy dose to these organs [42, 43]. Lin et al. retrospectively analyzed 580 patients with nCRT to investigate difference according to radiotherapy modality, including PBT, intensity modulated radiotherapy (IMRT), and threedimensional conformal techniques (3D-CRT) [44]. The incidence of pulmonary complications of PBT, IMRT, and 3D-CRT was $16.2 \%, 24.2 \%$, and $39.5 \%(p<0.01)$, respectively; the incidence of cardiac complications was $11.7 \%$, $11.7 \%$, and $27.4 \%$, respectively $(p<0.01)$. The non-statistically significant 90 -day postoperative mortality $(0.9 \%$, $4.3 \%$, and $4.2 \%$ in PBT, IMRT, and 3D-CRT, respectively) was the lowest in PBT $(p=0.26)$. The UICC retrospectively analyzed patients who underwent definitive CRT and showed significantly better 5-year OS (41.6\% vs. $31.6 \%, p=0.01$ ); PFS (34.9\% vs. $20.4 \%, p<0.01$ ); and distant metastasis-free survival (DMFS) (64.9\% vs $49.6 \%$, $p=0.03)$ in the PBT group compared with the IMRT group [43]. In subgroup analysis, no significant difference occurred in the 5-year OS, PFS, DMFS, and locoregional failure-free survival (LRFFS) in stage I/II; however, in stage III, the 5-year OS and PFS in the PBT group were significantly higher (34.6\% vs. $25.0 \%, p=0.04 ; 33.5 \%$ vs. $13.2 \%, p<0.01$, respectively) and the LRFFS was also better $(62.6 \%$ vs. $43.4 \%, p=0.051)$. It is questionable how the improvement in OS and decrease in treatment toxicity, including postoperative mortality, by PBT will affect the prognosis of patients with CR after nCRT. It is expected that ongoing prospective randomized trials, such as the NRG-GI006 (NCT03801876) and European PROTECT 
trial (IMI 101008134), will provide clues to these questions $[45,46]$.

This study has some limitations that should be considered when interpreting the results. First, five of the six studies selected were retrospective. Thus, selection bias could be inevitable between nCRT and nCRT plus surgery, and cofounding factors cannot be balanced. Second, the radiotherapy doses used in the included studies were heterogeneous, ranging from 30to $50.4 \mathrm{~Gy}$. A systematic analysis reported that higher radiation doses increased the probability of achieving PCR [47]. However, several studies showed no association between the radiotherapy dose and survival $[48,49]$. Rather, a high dose may be associated with inferior OS due to increased mortality after surgery [50]. Although not significant in our study, high mortality following nCRT plus surgery may have influenced the favorable outcome for nCRT alone; thus, a further study is needed to understand the optimal radiation dose in nCRT. Third, the analysis of longterm outcomes included limited survival data of only up to 2 years. However, there may be little difference in the survival tendency because most recurrence occur within 2 years. Current large prospective studies, such as the SANO- and ESOSTRATE-trials, will resolve this limitation. Fourth, subgroup analyses of esophageal ACC and SCC could not be performed because all included studies did not provide treatment result according to histology. Most patients in this meta-analysis had SCC, which is generally known to be more sensitive to CRT. Although there is no significant difference in the complete response rates between ACC and SCC (median 22.0\% [range, $9.0 \%-40.0 \%$ ] vs. $23.7 \%$ (range, $16.0 \%-41.0 \%$ ) [51], further research on the feasibility of omitting surgery after nCRT in ACC is needed. Further prospective randomized controlled clinical trials with large sample sizes are also needed to validate our findings.

\section{Conclusion}

The findings of this systematic review and meta-analysis showed that nCRT alone provides better OS benefit than nCRT plus surgery in complete responders after nCRT. Adding surgery could increase the morbidity and mortality and decrease the QOL. Thus, nCRT without surgery could be a feasible approach for patients with cCR.

\footnotetext{
Abbreviations

nCRT: Neoadjuvant chemoradiotherapy; CRT: Chemoradiotherapy; LF: Local failure; OS: Overall survival; DFS: Disease-free survival; DM: Distant metastasis; CCR: Clinical complete response; RR: Relative risk; HR: Hazard ratio; Cl: Confidence interval; SCC: Squamous cell carcinoma; ACC: Adenocarcinoma; LR: Locoregional recurrence; pCR: Pathologic CR; EUS: Endoscopic ultrasonography; CT: Computed tomography; PET: Positron emission tomography; MRI: Magnetic resonance imaging (MRI); QOL: Quality of life.
}

\section{Supplementary Information}

The online version contains supplementary material available at https://doi. org/10.1186/s13014-021-01947-7.

Additional file 1. Table S1: Quality assessment of the included retrospective studies according to the Newcastle-Ottawa Scale (NOS).

Additional file 2. Table S2: Sensitive analysis: (A) overall survival, (B) disease-free survival, (C) locoregional failure, (D) distant failure, and (E) treatment mortality.

Additional file 3. Fig. S1: The Cochrane Collaboration's tool for the quality assessment of prospective studies.

Additional file 4. Fig. S2: Funnel test for publication bias: (a) overall survival, (b) disease-free survival, (c) locoregional failure, (d) distant failure and (e) treatment mortality.

\section{Acknowledgements}

This work was supported by the National Research Foundation of Korea (NRF-2019M3E5D1A02068143).

\section{Authors' contributions}

PJH and PJW performed the literature review. PJW and PJH performed major conceptualization of this study. PJH performed the statistical analysis and drafted the manuscript. PJW supported with funding resources. PJW and YJW participated in its design and coordination, and also reviewed the manuscript. All authors read and approved the final manuscript.

\section{Funding}

This work was supported by the National Research Foundation of Korea [NRF-2019M3E5D1A02068143].

This work was supported by the National Research Foundation of Korea [NRF-2019M3E5D1A02068143].

\section{Availability of data and materials}

All data are fully available without restriction.

\section{Declarations}

Ethics approval and consent to participate Not applicable.

Consent for publication

Not applicable.

Competing interests

The authors declare that they have no competing interests.

Received: 3 August 2021 Accepted: 3 November 2021

Published online: 14 November 2021

\section{References}

1. Arnold M, Soerjomataram I, Ferlay J, Forman D. Global incidence of oesophageal cancer by histological subtype in 2012. Gut. 2015;64(3):381-7.

2. Gupta B, Kumar N. Worldwide incidence, mortality and time trends for cancer of the oesophagus. Eur J Cancer Prev. 2017;26(2):107-18.

3. Siegel RL, Miller KD, Jemal A. Cancer statistics, 2020. CA Cancer J Clin. 2020;70(1):7-30.

4. van Hagen P, Hulshof MC, van Lanschot JJ, Steyerberg EW, van Berge Henegouwen MI, Wijnhoven BP, et al. Preoperative chemoradiotherapy for esophageal or junctional cancer. N Engl J Med. 2012;366(22):2074-84.

5. Bedenne L, Michel P, Bouche O, Milan C, Mariette C, Conroy T, et al. Chemoradiation followed by surgery compared with chemoradiation 
alone in squamous cancer of the esophagus: FFCD 9102. J Clin Oncol. 2007;25(10):1160-8.

6. Vellayappan BA, Soon YY, Ku GY, Leong CN, Lu JJ, Tey JC. Chemoradiotherapy versus chemoradiotherapy plus surgery for esophageal cancer. Cochrane Database Syst Rev. 2017:8:Cd010511.

7. Stahl M, Stuschke M, Lehmann N, Meyer HJ, Walz MK, Seeber S, et al. Chemoradiation with and without surgery in patients with locally advanced squamous cell carcinoma of the esophagus. J Clin Oncol. 2005;23(10):2310-7.

8. Dewan A, Sharma SK, Dewan AK, Khurana R, Gupta M, Pahuja A, et al. Impact on radiological and pathological response with neoadjuvant chemoradiation and its effect on survival in squamous cell carcinoma of thoracic esophagus. J Gastrointest Cancer. 2017;48(1):42-9.

9. Maas M, Beets-Tan RG, Lambregts DM, Lammering G, Nelemans PJ, Engelen SM, et al. Wait-and-see policy for clinical complete responders after chemoradiation for rectal cancer. J Clin Oncol. 2011;29(35):4633-40.

10. Agoston AT, Zheng Y, Bueno R, Lauwers GY, Odze RD, Srivastava A. Predictors of disease recurrence and survival in esophageal adenocarcinomas with complete response to neoadjuvant therapy. Am J Surg Pathol. 2015;39(8):1085-92.

11. Alnaji RM, Du W, Gabriel E, Singla S, Attwood K, Nava H, et al. Pathologic complete response is an independent predictor of improved survival following neoadjuvant chemoradiation for esophageal adenocarcinoma. J Gastrointest Surg. 2016;20(9):1541-6.

12. Park SR, Yoon DH, Kim JH, Kim YH, Kim HR, Lee HJ, et al. A randomized phase III trial on the role of esophagectomy in complete responders to preoperative chemoradiotherapy for esophageal squamous cell carcinoma (ESOPRESSO). Anticancer Res. 2019;39(9):5123-33.

13. Tierney JF, Stewart LA, Ghersi D, Burdett S, Sydes MR. Practical methods for incorporating summary time-to-event data into meta-analysis. Trials. 2007;8:16.

14. Jeong Y, Kim JH, Kim SB, Yoon DH, Park SI, Kim YH, et al. Role of surgical resection in complete responders on FDG-PET after chemoradiotherapy for locally advanced esophageal squamous cell carcinoma. J Surg Oncol. 2014;109(5):472-7.

15. Castoro C, Scarpa M, Cagol M, Alfieri R, Ruol A, Cavallin F, et al. Complete clinical response after neoadjuvant chemoradiotherapy for squamous cell cancer of the thoracic oesophagus: is surgery always necessary? J Gastrointest Surg. 2013;17(8):1375-81.

16. Chao YK, Tseng CK, Wen YW, Liu YH, Wan YL, Chiu CT, et al. Using pretreatment tumor depth and length to select esophageal squamous cell carcinoma patients for nonoperative treatment after neoadjuvant chemoradiotherapy. Ann Surg Oncol. 2013;20(9):3000-8.

17. Piessen G, Messager M, Mirabel X, Briez N, Robb WB, Adenis A, et al. Is there a role for surgery for patients with a complete clinical response after chemoradiation for esophageal cancer? An intention-to-treat casecontrol study. Ann Surg. 2013;258(5):793-9.

18. van der Wilk BJ, Noordman BJ, Neijenhuis LKA, Nieboer D, Nieuwenhuijzen GAP, Sosef MN, et al. Active surveillance versus immediate surgery in clinically complete responders after neoadjuvant chemoradiotherapy for esophageal cancer: a multicenter propensity matched study. Ann Surg. 2019;6:66.

19. Sohda M, Kumakura Y, Saito H, Kuriyama K, Yoshida T, Honjyo H, et al. Clinical significance of salvage esophagectomy for patients with esophageal cancer and factors of influencing long-term survival. Anticancer Res. 2017;37(9):5045-51.

20. Steffen T, Dietrich D, Schnider A, Kettelhack C, Huber O, Marti WR, et al. Recurrence patterns and long-term results after induction chemotherapy, chemoradiotherapy, and curative surgery in patients with locally advanced esophageal cancer. Ann Surg. 2019;269(1):83-7.

21. Noordman BJ, Spaander MCW, Valkema R, Wijnhoven BPL, van Berge Henegouwen MI, Shapiro J, et al. Detection of residual disease after neoadjuvant chemoradiotherapy for oesophageal cancer (preSANO): a prospective multicentre, diagnostic cohort study. Lancet Oncol. 2018;19(7):965-74.

22. Eyck BM, Onstenk BD, Noordman BJ, Nieboer D, Spaander MCW, Valkema $R$, et al. Accuracy of detecting residual disease after neoadjuvant chemoradiotherapy for esophageal cancer: a systematic review and meta-analysis. Ann Surg. 2020;271(2):245-56.

23. van Rossum PSN, Goense L, Meziani J, Reitsma JB, Siersema PD, Vleggaar FP, et al. Endoscopic biopsy and EUS for the detection of pathologic complete response after neoadjuvant chemoradiotherapy in esophageal cancer: a systematic review and meta-analysis. Gastrointest Endosc. 2016;83(5):866-79

24. Cheedella NK, Suzuki A, Xiao L, Hofstetter WL, Maru DM, Taketa T, et al. Association between clinical complete response and pathological complete response after preoperative chemoradiation in patients with gastroesophageal cancer: analysis in a large cohort. Ann Oncol. 2013;24(5):1262-6.

25. van Rossum PS, van Lier AL, van Vulpen M, Reerink O, Lagendijk JJ, Lin SH, et al. Diffusion-weighted magnetic resonance imaging for the prediction of pathologic response to neoadjuvant chemoradiotherapy in esophageal cancer. Radiother Oncol. 2015;115(2):163-70.

26. Heethuis SE, Goense L, van Rossum PSN, Borggreve AS, Mook S, Voncken FEM, et al. DW-MRI and DCE-MRI are of complementary value in predicting pathologic response to neoadjuvant chemoradiotherapy for esophageal cancer. Acta Oncol. 2018;57(9):1201-8.

27. Borggreve AS, Goense L, van Rossum PSN, Heethuis SE, van Hillegersberg $\mathrm{R}$, Lagendijk JJW, et al. Preoperative prediction of pathologic response to neoadjuvant chemoradiotherapy in patients with esophageal cancer using (18)F-FDG PET/CT and DW-MRI: a prospective multicenter study. Int J Radiat Oncol Biol Phys. 2020;106(5):998-1009.

28. Sherry AD, Newman NB, Anderson JL, Osmundson EC. Systemic inflammatory dynamics during chemoradiotherapy predict response, relapse, metastasis, and survival in esophageal carcinoma. J Surg Oncol. 2019;6:66.

29. Maher SG, McDowell DT, Collins BC, Muldoon C, Gallagher WM, Reynolds $\mathrm{JV}$. Serum proteomic profiling reveals that pretreatment complement protein levels are predictive of esophageal cancer patient response to neoadjuvant chemoradiation. Ann Surg. 2011;254(5):809-16 (discussion 16-17).

30. Zhang SS, Huang QY, Yang H, Xie X, Luo KJ, Wen J, et al. Correlation of p53 status with the response to chemotherapy-based treatment in esophageal cancer: a meta-analysis. Ann Surg Oncol. 2013;20(7):2419-27.

31. Tanaka K, Mohri Y, Ohi M, Yokoe T, Koike Y, Morimoto Y, et al. Excisionrepair cross-complementing 1 predicts response to cisplatin-based neoadjuvant chemoradiotherapy in patients with esophageal squamous cell carcinoma. Mol Med Rep. 2009;2(6):903-9.

32. Metzger R, Warnecke-Eberz U, Alakus H, Kütting F, Brabender J, Vallböhmer $D$, et al. Neoadjuvant radiochemotherapy in adenocarcinoma of the esophagus: ERCC1 gene polymorphisms for prediction of response and prognosis. J Gastrointest Surg. 2012;16(1):26-34 (discussion).

33. Boshier PR, Klevebro F, Savva KV, Waller A, Hage L, Hanna GB, et al. Assessment of health related quality of life and digestive symptoms in longterm, disease free survivors after esophagectomy. Ann Surg. 2020;6:66.

34. Noordman BJ, Verdam MGE, Onstenk B, Heisterkamp J, Jansen W, Martijnse IS, et al. Quality of life during and after completion of neoadjuvant chemoradiotherapy for esophageal and junctional cancer. Ann Surg Oncol. 2019;26(13):4765-72.

35. Swisher SG, Wynn P, Putnam JB, Mosheim MB, Correa AM, Komaki RR, et al. Salvage esophagectomy for recurrent tumors after definitive chemotherapy and radiotherapy. J Thorac Cardiovasc Surg. 2002;123(1):175-83.

36. Meunier B, Raoul J, Le Prise E, Lakehal M, Launois B. Salvage esophagectomy after unsuccessful curative chemoradiotherapy for squamous cell cancer of the esophagus. Dig Surg. 1998;15(3):224-6.

37. Nakamura T, Hayashi K, Ota M, Eguchi R, Ide H, Takasaki K, et al. Salvage esophagectomy after definitive chemotherapy and radiotherapy for advanced esophageal cancer. Am J Surg. 2004;188(3):261-6.

38. Tomimaru Y, Yano M, Takachi K, Miyashiro I, Ishihara R, Nishiyama K, et al. Factors affecting the prognosis of patients with esophageal cancer undergoing salvage surgery after definitive chemoradiotherapy. J Surg Oncol. 2006;93(5):422-8.

39. Oki E, Morita M, Kakeji Y, Ikebe M, Sadanaga N, Egasira A, et al. Salvage esophagectomy after definitive chemoradiotherapy for esophageal cancer. Dis Esophagus. 2007;20(4):301-4.

40. Swisher SG, Marks J, Rice D. Salvage esophagectomy for persistent or recurrent disease after definitive chemoradiation. Ann Cardiothorac Surg. 2017:6(2):144-51.

41. Newhauser WD, Zhang R. The physics of proton therapy. Phys Med Biol. 2015;60(8):R155-209.

42. Shiraishi Y, Xu C, Yang J, Komaki R, Lin SH. Dosimetric comparison to the heart and cardiac substructure in a large cohort of esophageal cancer 
patients treated with proton beam therapy or Intensity-modulated radiation therapy. Radiother Oncol. 2017;125(1):48-54.

43. Xi M, Xu C, Liao Z, Chang JY, Gomez DR, Jeter M, et al. Comparative outcomes after definitive chemoradiotherapy using proton beam therapy versus intensity modulated radiation therapy for esophageal cancer: a retrospective, single-institutional analysis. Int J Radiat Oncol Biol Phys. 2017:99(3):667-76.

44. Lin SH, Merrell KW, Shen J, Verma V, Correa AM, Wang L, et al. Multi-institutional analysis of radiation modality use and postoperative outcomes of neoadjuvant chemoradiation for esophageal cancer. Radiother Oncol. 2017;123(3):376-81

45. Comparing Proton Therapy to Photon Radiation Therapy for Esophageal Cancer. Journal. (^Issue);2021.

46. Proton versus photon therapy for esophageal cancer-a trimodality strategy. Journal. ;2021.

47. Geh Jl, Bond SJ, Bentzen SM, Glynne-Jones R. Systematic overview of preoperative (neoadjuvant) chemoradiotherapy trials in oesophageal cancer: evidence of a radiation and chemotherapy dose response. Radiother Oncol. 2006;78(3):236-44.
48. Yang Y, Xu X, Zhou X, Bao W, Zhang D, Gu F, et al. Impact of radiation dose on survival for esophageal squamous cell carcinoma treated with neoadjuvant chemoradiotherapy. Front Oncol. 2020;10:1431.

49. Buckstein M, Rhome R, Ru M, Moshier E. Neoadjuvant chemoradiation radiation dose levels for surgically resectable esophageal cancer: predictors of use and outcomes. Dis Esophagus. 2018;5:31.

50. Ji KSY, Thomas SM, Roman SA, Czito B, Anderson KL Jr, Frakes J, et al. Lowvs. high-dose neoadjuvant radiation in trimodality treatment of locally advanced esophageal cancer. J Gastrointest Surg. 2019;23(5):885-94

51. Bollschweiler E, Holscher AH, Metzger R. Histologic tumor type and the rate of complete response after neoadjuvant therapy for esophageal cancer. Future Oncol. 2010;6(1):25-35.

\section{Publisher's Note}

Springer Nature remains neutral with regard to jurisdictional claims in published maps and institutional affiliations.
Ready to submit your research? Choose BMC and benefit from:

- fast, convenient online submission

- thorough peer review by experienced researchers in your field

- rapid publication on acceptance

- support for research data, including large and complex data types

- gold Open Access which fosters wider collaboration and increased citations

- maximum visibility for your research: over $100 \mathrm{M}$ website views per year

At BMC, research is always in progress.

Learn more biomedcentral.com/submissions 